\title{
Association of Vitamin D Receptor Polymorphisms (FokI (Rs2228570), ApaI (Rs7975232), BsmI (Rs1544410), and TaqI (Rs731236)) with Gastric Cancer in a Kurdish Population from West of Iran
}

\author{
Zohreh Hoseinkhani ${ }^{1}$, Mohsen Rastegari-Pouyani ${ }^{2}$, Farahnaz Tajemiri ${ }^{1}$, \\ Kheirollah Yari ${ }^{1}$, Kamran Mansouri*1
}

\begin{abstract}
Background: The association of 1,25-dihydroxy vitamin D3 $(1,25(\mathrm{OH}) 2 \mathrm{D} 3)$ and its receptor, vitamin D receptor (VDR), with cancer types have been studied. However, there are controversial findings regarding the association of specific VDR polymorphisms with different kinds of cancers. In the current study, we investigated the association of VDR polymorphisms (Fok1 (rs2228570), ApaI (rs7975232), BsmI (rs1544410), and TaqI (rs731236)) with the risk of gastric cancer in a Kurdish population of Kermanshah in Iran for the first time.

Methods: In this case-control study, the polymerase chain reaction-restriction fragment length polymorphism (PCR-RFLP) method was used in 99 gastric cancer patients and 100 healthy subjects as controls.

Results: The frequencies of $\mathrm{f}(\mathrm{FokI}), \mathrm{b}(\mathrm{Bsml}), \mathrm{t}(\mathrm{TaqI})$, and a (Apal) alleles were: $55.6 \%, 27.3 \%, 62.1 \%$, and $44.95 \%$ in the patient group, respectively and $42 \%, 29.5 \%, 54.5 \%$, and $46.0 \%$ in the control group, respectively. Analysis of the results indicated that there was a positive association between the frequency of FokI genotypes with gastric cancer risk $(p=0.021)$. However, no statistically significant association of BsmI, Taq1, and ApaI polymorphisms of VDR was detected in gastric patients when compared with healthy individuals.
\end{abstract}

Conclusions: VDR-FokI polymorphism could increase the risk of GC development and predispose to the disease by mechanisms.

Keywords: Gastric cancer, PCR-RFLP, Polymorphism, Vitamin D receptor.

\section{Introduction}

Gastric cancer, as the second most prevalent tumor worldwide, originates from the lining of the stomach and is a significant global threat to public health (1-3). Gastric carcinogenesis is a multifactorial process in which genetic and environmental factors are both implicated (4). In this regard, the vitamin $\mathrm{D}$ receptor $(V D R)$ gene has been a research focus due to its essential roles in the regulation of cell proliferation, differentiation as well as apoptosis. The VDR maps to the chromosome region 12q13.1 with a length of 63493 nucleotides and spans approximately $75 \mathrm{~kb}(5,6)$.

The $V D R$, as a member of the steroid hormone receptor family, specifically binds vitamin $\mathrm{D}$ or $1,25(\mathrm{OH})_{2} \mathrm{D}$ mediating its effects

1: Medical Biology Research Center, Health Technology Institute, Kermanshah University of Medical Sciences, Kermanshah, Iran. 2: Student Research Committee, Department of Immunology, School of Medicine, Shahid Beheshti University of Medical Sciences, 
$(7,8)$. As one of its key roles, vitamin D can affect cancer growth and expansion via multiple signaling pathways implicated in cell apoptosis, proliferation, invasion, and metastasis. Low 1,25 $(\mathrm{OH})_{2} \mathrm{D}_{3}$ serum levels are associated with cancer progression (9). Various studies by elucidating their anticancer activities and the related underlying mechanisms have addressed the involvement of VDR and vitamin D in cancer. In 1981, $1,25(\mathrm{OH})_{2} \mathrm{D}_{3}$ showed its ability to significantly inhibit the proliferation of melanoma cells in vitro at Nano molar concentrations (10). Various VDR signaling-mediated mechanisms account for the mentioned anti-tumor effects. For instance, VDR signaling can induce G0/G1 cell cycle arrest coupled with upregulation of several inhibitors of cell cycle like P21 and P27. Also, it can induce cell cycle arrest at $\mathrm{G} 2 / \mathrm{M}$ and increase the expression of E-cadherin and desmosomes that lead to apoptosis and enhance adhesion and suppress the migration of cancer cells. Epidemiological evidence has highlighted an inverse correlation between the intensity of local sunlight and the risk of some cancers, allegorically prostate and breast cancer (9). Also, VDR-Knock out mice shows a higher tendency to develop cancer following challenge with carcinogens (11). The VDR gene variants, including BsmI (rs1544410, intron 8, +63980 G>A), TaqI (rs731236, exon 9, +65058 T $>\mathrm{C}$ ), and ApaI (rs7975232, intron 8, $+64978 \mathrm{C}>\mathrm{A}$ ) have been located in the 3' end region of the VDR gene, whereas FokI (rs2228570, rs10735810, exon 2, $+30920 \mathrm{C}>\mathrm{T})$ is found at the translation start codon $(12,13)$. Previous studies have revealed that single nucleotide polymorphisms (SNPs) of the VDR gene (BsmI, TaqI, ApaI, FokI) associate with the risk of cancer development (14-16).

The current study aimed to study the association and role of the VDR gene polymorphisms in gastric cancer and the frequencies of VDR-Fok1, VDR-ApaI, VDRBsmI, and VDR-TaqI polymorphisms in patients with gastric cancer compared to healthy individuals.

\section{Materials and Methods \\ Materials}

The DNA extraction kit, agarose, Taq polymerase, $\mathrm{MgCl}_{2}$, buffer, and dNTPs used for polymerase chain reactions (PCR) were purchased from Pishgam Co. (Tehran, Iran). The BsmI, ApaI, TaqI, and FokI restriction enzymes were from Thermo Scientific Fermentas. All other reagents and chemicals were obtained from Sigma (USA). The primers were synthesized by Pishgam Co. (Tehran, Iran).

\section{Sample collection}

A total of 99 patients (47 males and 52 females) with gastric cancer with a mean age of $56 \pm 8.43$ years and 100 healthy controls (56 males and 44 females) with a mean age of $37 \pm 7.43$ years were enrolled in this study. Five $\mathrm{mL}$ of the blood samples were obtained from every patient and control individuals. All the studied individuals had the Kurdish ethnicity and were from the west of Iran. Ethics Committee in Kermanshah University of Medical Sciences, Iran, approved the current study (No. 97402). All individuals agreed and signed the form of informed consent (Helsinki II declaration).

\section{DNA extraction and Genotyping}

The extraction of genomic DNA from peripheral blood samples was carried out using the DNA extraction kit (Pishgam Co.). To investigate VDR-ApaI, BsmI, FokI, and TaqI polymorphisms, the polymerase chain reaction-restriction fragment length polymorphism (PCR-RFLP) technique was applied $(17,18)$. Specific PCR primers were designed using robust oligo primer design software and SNP database (dbSNP, http://www.ncbi.nlm.nih.gov/projects/SNP)

(Table 1).

\section{Statistical Analysis}

Immunoblot data were quantified by densitometry and presented in means \pm standard deviation of at least two replicates. Statistical analysis was accomplished using Student's ttest in Microsoft Excel, with p-values less than 0.05 considered as statistically significant. 
Table 1. The sequence of the primers and PCR-RFLP products characteristics.

\begin{tabular}{|c|c|c|c|}
\hline Primer name & Sequence & $\begin{array}{l}\text { PCR product } \\
\text { (bp) }\end{array}$ & $\begin{array}{l}\text { Digested length } \\
\text { (bp) }\end{array}$ \\
\hline $\begin{array}{l}\text { FokI-F } \\
\text { FokI-R }\end{array}$ & $\begin{array}{l}\text { TCCCTGGCACTGACTCTGGCTTT } \\
\text { GAAACACCTTGCTTCTTCTCCGT }\end{array}$ & 259 & 194,65 \\
\hline $\begin{array}{l}\text { BsmI-F } \\
\text { BsmI-R }\end{array}$ & $\begin{array}{l}\text { CAACCAAGACTACAAGTACCGC } \\
\text { AACCAGCGGAAGAGGTCAAGG }\end{array}$ & 822 & 648,174 \\
\hline $\begin{array}{l}\text { TaqI-F } \\
\text { TaqI-R }\end{array}$ & $\begin{array}{l}\text { AGAGCATGGACAGGGAGCAAG } \\
\text { GCAACTCCTCATGGCTGAGGTCT }\end{array}$ & 744 & 247,497 \\
\hline $\begin{array}{l}\text { ApaI-F } \\
\text { ApaI-R }\end{array}$ & $\begin{array}{l}\text { AGAGCATGGACAGGGAGCAAG } \\
\text { GCAACTCCTCATGGCTGAGGTCT }\end{array}$ & 744 & 212,532 \\
\hline
\end{tabular}

The used primers are presented in Table 1. The PCR-RFLP method was performed in $25 \mu \mathrm{L}$ reaction volumes containing $10 \mathrm{X}$ buffer (100 $\mathrm{mM}$ Tris- $\mathrm{HCl}, 50 \mathrm{mM} \mathrm{MgCl} 2,500 \mathrm{mM} \mathrm{KCl}, \mathrm{pH}$ 8.3), $0.2 \mathrm{mM}$ dNTPs, $200 \mathrm{ng}$ template DNA, and $1 \mathrm{U}$ AmpliTaq DNA polymerase. The touchdown PCR program was performed. The following steps, for FokI: one cycle of initial denaturation for $10 \mathrm{~min}$ at $95^{\circ} \mathrm{C}$, then 35 cycles of denaturation for $45 \mathrm{sec}$ at $94{ }^{\circ} \mathrm{C}$ followed by annealing for $45 \mathrm{sec}$ at $62{ }^{\circ} \mathrm{C}$, and final extension for $10 \mathrm{~min}$ at $72{ }^{\circ} \mathrm{C}$; for $\mathrm{BsmI}$ : one cycle of initial denaturation for $10 \mathrm{~min}$ at $95{ }^{\circ} \mathrm{C}$, then 35 cycles of denaturation for $45 \mathrm{sec}$ at $94{ }^{\circ} \mathrm{C}$ followed by annealing for $45 \mathrm{sec}$ at $60{ }^{\circ} \mathrm{C}$, and final extension for $7 \mathrm{~min}$ at $72{ }^{\circ} \mathrm{C}$; for TaqI: one cycle of initial denaturation for $10 \mathrm{~min}$ at $95{ }^{\circ} \mathrm{C}$, then 35 cycles of denaturation for $45 \mathrm{sec}$ at $94{ }^{\circ} \mathrm{C}$ followed by annealing for $45 \mathrm{sec}$ at $61^{\circ} \mathrm{C}$, and final extension for $10 \mathrm{~min}$ at $72{ }^{\circ} \mathrm{C}$; and for Apal: one cycle of initial denaturation for $10 \mathrm{~min}$ at $95{ }^{\circ} \mathrm{C}$, then 35 cycles of denaturation for $45 \mathrm{sec}$ at $94{ }^{\circ} \mathrm{C}$ followed by annealing for $40 \mathrm{sec}$ at $58{ }^{\circ} \mathrm{C}$ and final extension for $10 \mathrm{~min}$ at $72{ }^{\circ} \mathrm{C}$.

The PCR products were separately digested for $24 \mathrm{~h}$ with FokI, BsmI, TaqI, and ApaI restriction enzymes at $37^{\circ} \mathrm{C}$ overnight for FokI, BsmI, TaqI, and ApaI SNPs, respectively (19). The digested PCR products underwent electrophoresed on $2 \%$ agarose gels and were detected via staining with GelRed DNA stain. For genotype sequencing, the samples were analyzed by a DNA sequencer apparatus (Macrogen, South Korea).

\section{Statistical analysis}

The genotype frequencies of VDR polymorphisms were compared using the Pearson's Chi-squared test in the IBM SPSS software using statistical package for social sciences (SPSS) version 18 and logistic regression analysis with $95 \%$ confidence intervals (CIs).

\section{Results}

Table 2 shows the frequency distribution of alleles and genotypes for the patients and control groups. Anal oysisf the 199 subjects, 99 gastric cancer patients and 100 healthy controls, showed that the frequency oft and $\mathrm{f}$ alleles was higher in the gastric cancer cases $(\mathrm{t}=62.1 \%, \mathrm{f}=55.6 \%)$ compared to controls $(\mathrm{t}=54.5 \%, \mathrm{f}=42 \%)$ while the frequencies of $\mathrm{a}$ and $\mathrm{b}$ alleles were lower in the gastric cancer cases $(a=44.95 \%, b=27.3 \%)$ compared to controls $(a=46 \%, b=29.5 \%)$ as presented in Table 2.

The frequencies of $\mathrm{f}(F o k I), \mathrm{b}(B s m I), \mathrm{t}$ (TaqI) and a (ApaI) alleles were: 55.6\%, $27.3 \%, 62.1 \%$ and $44.95 \%$ in the patient group, respectively and $42 \%, 29.5 \%, 54.5 \%$, and $46.0 \%$ in the control group, respectively. Analysis of the results indicated that there was a positive association between the frequency of FokI genotypes with gastric cancer risk $(\mathrm{p}=0.021)$. However, no statistically significant association of $B s m I$, Taq1, and ApaI polymorphisms of $V D R$ was detected in gastric patients when compared with healthy individuals. The results of direct DNA sequencing of the patients with wild 
genotype and mutant genotype for each

polymorphism are also shown in Figure 1.

Table 2. Genotype and allele frequency (in percent) of BsmI, FokI, TaqI, and ApaI in gastric cancer cases and healthy controls.

\begin{tabular}{|c|c|c|c|c|}
\hline Genotype/allele & $\begin{array}{c}\text { Case group } \\
(\mathbf{n}=99)\end{array}$ & $\begin{array}{c}\text { Control group } \\
(n=100)\end{array}$ & $\begin{array}{l}P \text { value } \\
\text { interval }\end{array}$ & 95\% Confidence \\
\hline \multicolumn{5}{|c|}{ BsmI genotype (rs1544410) } \\
\hline $\mathrm{BB}$ & $62(62.6 \%)$ & $51(51 \%)$ & \multirow{6}{*}{0.347} & \multirow{6}{*}{$0.699(0.332-1.473)$} \\
\hline $\mathrm{Bb}$ & $20(20.2 \%)$ & $29(29 \%)$ & & \\
\hline $\mathrm{Bb}$ & $17(17.2 \%)$ & $20(20 \%)$ & & \\
\hline \multicolumn{3}{|l|}{ BsmI allele } & & \\
\hline $\mathrm{B}$ & $144(72.7 \%)$ & $131(70.5 \%)$ & & \\
\hline $\mathrm{B}$ & $54(27.3 \%)$ & $69(29.5 \%)$ & & \\
\hline \multicolumn{3}{|l|}{ FokI genotype (rs2228570) } & \multirow{7}{*}{0.021} & \multirow{7}{*}{$2.240(1.132-4.431)$} \\
\hline $\mathrm{FF}$ & $32(32.3 \%)$ & $40(40 \%)$ & & \\
\hline Ff & $24(24.2 \%)$ & $36(36 \%)$ & & \\
\hline $\mathrm{ff}$ & $43(43.4 \%)$ & $24(24 \%)$ & & \\
\hline \multicolumn{3}{|l|}{ FokI allele } & & \\
\hline $\mathrm{F}$ & $88(44.4 \%)$ & $116(58 \%)$ & & \\
\hline $\mathrm{F}$ & $110(55.6 \%)$ & $84(42 \%)$ & & \\
\hline \multicolumn{3}{|l|}{ TaqI genotype (rs731236) } & \multirow{7}{*}{0.272} & \multirow{7}{*}{$1.453(0.746-2.829)$} \\
\hline $\mathrm{TT}^{1}$ & $27(27.3 \%)$ & $30(30 \%)$ & & \\
\hline $\mathrm{Tt}$ & $21(21.2 \%)$ & $31(31 \%)$ & & \\
\hline $\mathrm{tt}$ & $51(51.5 \%)$ & $39(39 \%)$ & & \\
\hline \multicolumn{3}{|l|}{ TaqI allele } & & \\
\hline $\mathrm{T}$ & $75(37.9 \%)$ & $91(45.5 \%)$ & & \\
\hline $\mathrm{T}$ & $123(62.1 \%)$ & $109(54.5 \%)$ & & \\
\hline \multicolumn{3}{|l|}{ ApaI genotype (rs7975232) } & \multirow{7}{*}{0.916} & \multirow{7}{*}{$0.966(0.507-1.842)$} \\
\hline AA & $44(44.4 \%)$ & $40(40 \%)$ & & \\
\hline $\mathrm{Aa}$ & $21(21.3 \%)$ & $28(28 \%)$ & & \\
\hline aa & $34(34.3 \%)$ & $32(32 \%)$ & & \\
\hline \multicolumn{3}{|l|}{ ApaI allele } & & \\
\hline A & $55.05 \%$ & $108(58 \%)$ & & \\
\hline A & $44.95 \%$ & $92(46 \%)$ & & \\
\hline
\end{tabular}

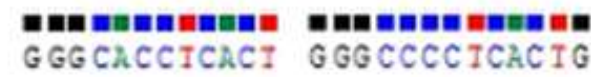

A)

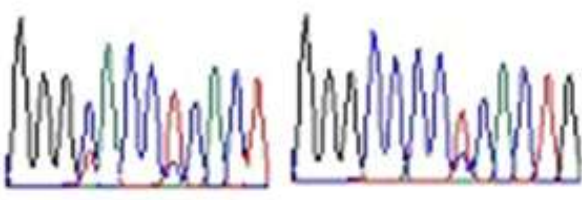

CA

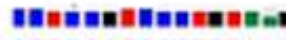

cozcotccotgraxg

CC

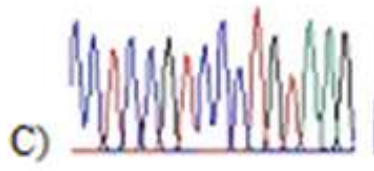

GT

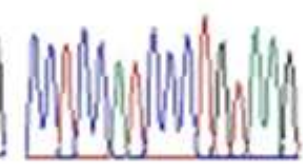

AT

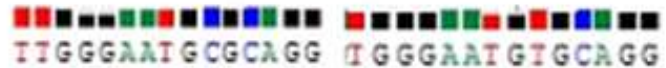

B)

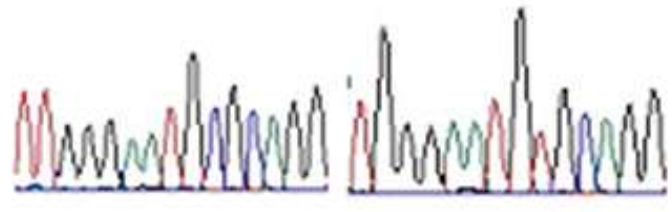

GC

GT

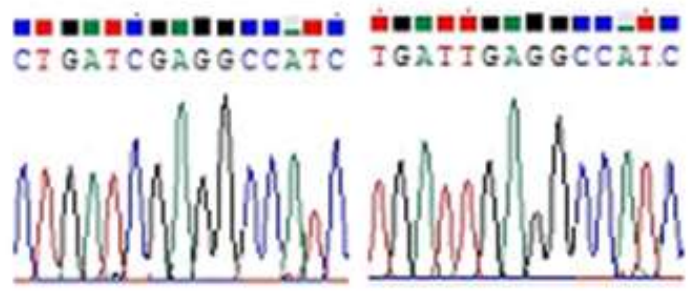

CG
TG

Fig. 1. Sequence analysis of DNA samples. A; The sequence of ApaI (C>A) polymorphism with A and C alleles, B; BsmI polymorphism with $\mathrm{C}$ and $\mathrm{T}$ alleles (sequenced with reverse primer), C; FokI polymorphism with $\mathrm{G}$ and $\mathrm{A}$ alleles (sequenced with reverse primer), D; TaqI polymorphism ( $\mathrm{T}>\mathrm{C})$ with $\mathrm{C}$ and $\mathrm{T}$ alleles. 


\section{Discussion}

In recent years, numerous studies have been conducted on the association between $V D R$ gene polymorphism and various types of cancer, and it is hypothesized that the polymorphism of this gene might affect the risk of cancer development and its prognosis (20). Vitamin D receptor (VDR)is a high-affinity receptor that serves as a transcription factor upon ligand binding and activation. Ligand binding triggers its hetero dimerization with $\mathrm{x}$ retinoid receptor $(21,22)$. The activated high-affinity heterodimer binds to the vitamin D response elements located within the promoter regions of the target genes adjacent to the transcriptional machinery $(22,23)$. More than 60 different types of polymorphisms have been identified within this gene, most notably FokI, BsmI, ApaI, and TaqI (24). Various reports have been presented on the association of VDR polymorphisms with breast, skin, and prostate cancers (25).

FokI is located at the 5' end of the VDR gene. In this SNP, due to the nucleotide substitution of $\mathrm{T}$ to $\mathrm{C}$ within the first codon of exon 2 (ATG to ACG giving rise to the allelic conversion of " $\mathrm{f}$ " to " $F$ "), the first translation initiation site (TIS) is eliminated ultimately resulting in the production of a peptide shorter than the wild type peptide (3 amino acids absent) hence creating a new form of VDR which is more transcriptionally active (25). Concerning this VDR polymorphism, we detected a higher frequency of " $\mathrm{O}$ " allele in gastric cancer patients in comparison to healthy individuals. In line with our finding, Cong et al. in 2015 found a higher frequency of " $f$ " allele among gastric cancer patients compared to controls in a Chinese Han population (26). The TaqI polymorphism is located within exon 9, codon 352, in which a $\mathrm{T}$ nucleotide has been substituted with a C. Since VDR is a transcriptional regulating factor for a large number of target genes, its altered expression can influence various aspects of cellular function (27, 28). In this study, we found a higher frequency of TaqI polymorphism in gastric cancer patients. In a meta-analysis carried out by Serrano et al. in 2016 on the association of VDR polymorphisms with the risk of cancer, TaqI SNP was demonstrated to confer a $43 \%$ increased risk of colorectal cancer (CRC)as another cancer of the gastrointestinal (GI) tract (29). In a study, TaqI polymorphism was shown to significantly associate with vulnerability to Crohn's disease with an elevated TaqI " $t$ " allele frequency in these patients (30).

ApaI polymorphism, located within exon 9 adjacent to the $3^{\prime}$ untranslated region (3' UTR), negatively regulates VDR expression. In this SNP, G is replaced by T $(28,31)$. BsmI is located within intron 8 and near the 3'UTR region and is generated as a result of nucleotide substitution of $\mathrm{G}$ to A. This polymorphism also affects VDR mRNA stability (25). According to our results, ApaI and BsmI SNPs did not associate with gastric cancer. The same finding was reported by Vidigal et al. that, a heterozygous genotype of ApaI SNP (Aa) or the association genotype (aa+Aa) predisposed to CRC as a GI cancer whereas BsmI SNP did not significantly associate with the risk of CRC (32). Martins et al. reported that FokI, TaqI, and ApaI polymorphisms were not associated with Helicobacter pylori (H. pylori) infection, while BsmI polymorphism showed a possible association with infection byH. Pylori (33). Kevin et al., in a case-control study reported that serum vitamin D levels in gastric incomplete intestinal metaplasia patients were lower compared with healthy subjects (34).

In conclusion, the results of this study demonstrated that FokI polymorphism is associated with gastric cancer risk. However, TaqI ApaI and BsmI polymorphisms are not associated with gastric cancer. However, future researches with a larger sample size are needed to confirm these results. This study can be used as a basis for studying other polymorphisms of VDR in association with gastric cancer.

\section{Acknowledgements}

This research was supported by the Medical Biology Research Center (MBRC), Kermanshah University of Medical Sciences (KUMS). We would like to especially thank MrRezvanAsgari and Dr. Saeed Hamzehei for their discussions and help with manuscript preparation.

The authors declare that they have no conflict of interest. 


\section{Hoseinkhani Z et al}

\section{References}

1. Guo L-L, Song C-H, Wang P, Dai L-P, Zhang J-Y, Wang K-J. Competing endogenous RNA networks and gastric cancer. World $\mathbf{J}$ Gastroenterol. 2015;21(41):11680-7.

2. Al-Bayaty MK, Abass SA-R, Al-Marjani MF. E-Cadherin Protein as a Potential Marker for Gastric Cancer and Its Association with Helicobacter Pylori-Induced Gastritis and Gastric Ulcer. Rep Biochem Mol Biol. 2019;8(3):269-277.

3. Kazemi E, Kahrizi D, Moradi M, Sohrabi M, Amini S, Mousavi S, et al. Association between Helicobacter pylori hopQI genotypes and human gastric cancer risk. Cell Mol Biol (Noisy-legrand). 2016;62(1):6-9.

4. Moradi M-T, Yari K, Rahimi Z, Kazemi E, Shahbazi M. Manganese superoxide dismutase (MnSOD Val-9Ala) gene polymorphism and susceptibility to gastric cancer. Asian Pac J Cancer Prev. 2015;16(2):485-8.

5. Mittal RD, Manchanda PK, Bhat S, Bid HK. Association of vitamin-D receptor (Fok-I) gene polymorphism with bladder cancer in an Indian population. BJU Int. 2007;99(4):933-7.

6. Zmuda JM, Cauley JA, Ferrell RE. Molecular epidemiology of vitamin D receptor gene variants. Epidemiol Rev. 2000;22(2):203-17.

7. Naveh-Many T, Marx R, Keshet E, Pike J, Silver J. Regulation of 1, 25-dihydroxyvitamin D3 receptor gene expression by 1, 25dihydroxyvitamin D3 in the parathyroid in vivo. $\mathrm{J}$ Clin Invest. 1990;86(6):1968-75.

8. Mostafa-Hedeab G, Sabry D, Abdelaziz GM, Ewaiss M, Adli N, Fathy W. Influence of vitamin $\mathrm{D}$ receptor gene polymorphisms on response to pegylated interferon in chronic hepatitis B Egyptian patients. Rep Biochem Mol Biol. 2018;6(2):186-196.

9. Wen Y, Da M, Zhang Y, Peng L, Yao J, Duan Y. Alterations in vitamin D signaling pathway in gastric cancer progression: A study of vitamin D receptor expression in human normal premalignant, and malignant gastric tissue. Int J Clin Exp Pathol. 2015;8(10):13176-84.

10. Colston K, Colston MJ, Feldman D. 1, 25dihydroxyvitamin D3 and malignant melanoma: the presence of receptors and inhibition of cell growth in culture. Endocrinology. 1981;108(3):1083-6.

11. Thorne J, Campbell MJ. The vitamin D receptor in cancer: Symposium on 'Diet and cancer'. Proceedings of the Nutrition Society. 2008;67(2):115-27.

12. Abd-Elsalam EA-E, Ismaeil NA, AbdAlsalam HS. Vitamin D receptor gene polymorphisms and breast cancer risk among postmenopausal Egyptian women. Tumor Biol. 2015;36(8):6425-31.

13. Langdahl BL, Gravholt $\mathrm{CH}$, Brixen $\mathrm{K}$, Eriksen E. Polymorphisms in the vitamin D receptor gene and bone mass, bone turnover and osteoporotic fractures. Eur J Clin Invest. 2000;30(7):608-17.

14. McCullough ML, Stevens VL, Diver WR, Feigelson HS, Rodriguez C, Bostick RM, et al. Vitamin D pathway gene polymorphisms, diet, and risk of postmenopausal breast cancer: a nested case-control study. Breast Cancer Research. 2007;9(1):R9.

15. Guy M, Lowe LC, Bretherton-Watt D, Mansi JL, Peckitt C, Bliss J, et al. Vitamin D receptor gene polymorphisms and breast cancer risk. Clin Cancer Res. 2004;10(16):5472-81.

16. Taylor JA, Hirvonen A, Watson M, Pittman G, Mohler JL, Bell DA. Association of prostate cancer with vitamin $\mathrm{D}$ receptor gene polymorphism. Cancer Res. 1996;56(18):4108-10.

17. Hoseinkhani Z, Khodarahmi R, Sadeghalvad M, Norooznezhad F, Mansouri K. CYP2C9* 1*2 and VKORC1-1639 AA Polymorphisms Correlation with Warfarin Dose Requirement: A Case Report. Journal of Reports in Pharmaceutical Sciences. 2018;7(1):88-91.

18. Cheng W-C, Tsai K. The vitamin D receptor start codon polymorphism (Fok1) and bone mineral density in premenopausal women in Taiwan. Osteoporos Int. 1999;9(6):545-9.

19. Macdonald HM, McGuigan FE, Stewart A, Black AJ, Fraser WD, Ralston S, et al. Large-scale population-based study shows no evidence of association between common polymorphism of the VDR gene and BMD in 
British women. J Bone Miner Res. 2006;21(1):151-62.

20. Köstner K, Denzer N, Mueller CS, Klein R, Tilgen W, Reichrath J. The relevance of vitamin $\mathrm{D}$ receptor (VDR) gene polymorphisms for cancer: a review of the literature. Anticancer Res. 2009;29(9):3511-36.

21. Cheskis B, Freedman LP. Ligand modulates the conversion of DNA-bound vitamin D3 receptor (VDR) homodimers into VDR-retinoid $\mathrm{X}$ receptor heterodimers. Mol Cell Biol. 1994;14(5):3329-3338.

22. Freedman L, Arce V, Perez Fernandez R. DNA sequences that act as high affinity targets for the vitamin D3 receptor in the absence of the retinoid $\mathrm{X}$ receptor. Mol Endocrinol. 1994;8(3):265-73.

23. Nakajima S, Hsieh J-C, MacDonald PN, Galligan MA, Haussler CA, Whitfield GK, et al. The C-terminal region of the vitamin $\mathrm{D}$ receptor is essential to form a complex with a receptor auxiliary factor required for high affinity binding to the vitamin D-responsive element. Mol Endocrinol. 1994;8(2):159-72.

24. Acikbas I, Sanlı B, Tepeli E, Ergin S, Aktan S, Bagci H. Vitamin $D$ receptor gene polymorphisms and haplotypes (Apa I, Bsm I, Fok I, Taq I) in Turkish psoriasis patients. Med Sci Monit. 2012;18(11):CR661-6.

25. Grabiec M, Walentowicz P, Sadłecki P, Walentowicz-Sadłecka M. The role of vitamin D in the carcinogenesis of breast and ovarian cancer. Ginekologia polska. 2013;84(4):305-8.

26. Cong L, Wang W-b, Liu Q, Du J-j. FokI polymorphism of the vitamin $\mathrm{D}$ receptor gene is associated with susceptibility to gastric cancer: a case-control study. Tohoku J Exp Med. 2015;236(3):219-24.
27. Arababadi MK, Pourfathollah AA, Jafarzadeh A, Hassanshahi G, Rezvani ME. Association of exon 9 but not intron 8 VDR polymorphisms with occult HBV infection in south-eastern Iranian patients. J Gastroenterol Hepatol. 2010;25(1):90-3. 28. Mozaffarizadeh H, Hakimian M, Salehi M, Moazam E, Behjati M, Keshvari M, et al. The Relationship Between Breast Cancer and VDR Gene Polymorphisms. Archives of Breast Cancer. 2018:5;26-31.

29. Serrano D, Gnagnarella P, Raimondi S, Gandini S. Meta-analysis on vitamin D receptor and cancer risk: focus on the role of TaqI, ApaI, and Cdx2 polymorphisms. Eur J Cancer Prev. 2016;25(1):85-96.

30. Simmons J, Mullighan C, Welsh K, Jewell D. Vitamin D receptor gene polymorphism: association with Crohn's disease susceptibility. Gut. 2000;47(2):211-4.

31. Gao L, Tao Y, Zhang L, Jin Q. Vitamin D receptor genetic polymorphisms and tuberculosis: updated systematic review and meta-analysis. Int J Tuberc Lung Dis. 2010;14(1):15-23.

32. Vidigal VM, Silva TD, de Oliveira J, Pimenta CAM, Felipe AV, Forones NM. Genetic polymorphisms of vitamin $\mathrm{D}$ receptor (VDR), CYP27B1 and CYP24A1 genes and the risk of colorectal cancer. Int J Biol Markers. 2017;32(2):e224-e230.

33. de Jesus Martins D, Matos GC, Loiola RS, D'Annibale V, Corvelo T. Relationship of vitamin $\mathrm{D}$ receptor gene polymorphisms in Helicobacter pylori gastric patients. Clin Exp Gastroenterol. 2018;11:19-27.

34. Singh K, Gandhi S, Batool R. A Case-Control Study of the Association between Vitamin D Levels and Gastric Incomplete Intestinal Metaplasia. Nutrients. 2018;10(5):629. 